\title{
The Advocate
}

Volume 23

Number 3 Fall - Winter 2017

Article 1

$12-1-2016$

\section{Table of contents and introductory materials for Vol. 23, no. 3, 2017}

Bruce Quantic

Follow this and additional works at: https://newprairiepress.org/advocate

Part of the Teacher Education and Professional Development Commons

\section{Recommended Citation}

Quantic, Bruce (2016) "Table of contents and introductory materials for Vol. 23, no. 3, 2017," The Advocate: Vol. 23: No. 3. https://doi.org/10.4148/2637-4552.1022

This Introductory Material is brought to you for free and open access by New Prairie Press. It has been accepted for inclusion in The Advocate by an authorized administrator of New Prairie Press. For more information, please contactcads@k-state.edu. 


\title{
Table of contents and introductory materials for Vol. 23, no. 3, 2017
}

\author{
Abstract \\ Table of contents and introductory materials for Vol. 23, issue 3 (Fall - Winter 2017), including a \\ dedication to Dr. Donald E. Hufford (1929-2016), ATE-K member and reviewer/author.
}




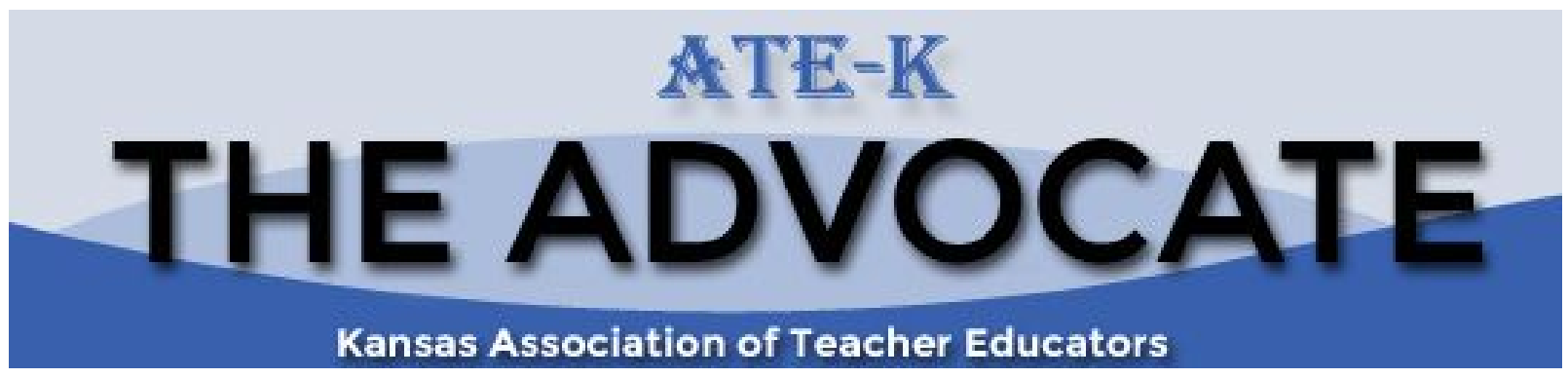

\title{
FALL - WINTER $2017 \quad$ VOL. 23, No. 3
}

\author{
The official publication of the \\ Association of Teacher Educators - Kansas
}

Dr. Bruce Quantic, Editor

Matthew S. Curtis, Web Content Manager / Layout Editor

Association of Teacher Educators - Kansas Executive Council

Dr. Laurie Curtis, President

Kansas State University

Dr. Dan Stiffler, Vice-President

Emporia State University

Dr. Jill Gonzalez-Bravo, Secretary

MidAmerica Nazarene University

Dr. Tim Fry, Executive Director

Washburn University 


\section{Greetings from ATE-K,}

Our organization is in a state of change. It seems that new initiatives are being launched regarding nearly every facet of our profession including new standards, new accreditation systems and new funding formulas. The same holds true for our $\mathrm{K}-12$ partners. As mentioned at our fall conference, we need to meet change with optimism! We need to...

Communicate. We need to be in discussion about all new initiatives that we are involved with, seeking opportunities for academic discourse regarding not only the changes we are encountering but the challenges and opportunities they present.

Help our K-12 partners embrace these new changes by sending them the best-informed pre-service teachers possible, i.e. candidates who understand things such as the Rose Capacities, Individual Plans of Study, innovative tools and strategies-teachers that know how to meet the needs of all their students.

Advocate! We need to tell our stories, celebrate our successes and advocate for the profession of teaching every chance we get!

Believe that No problem is too large that it can't be addressed through collaborative efforts between our institutions and our K-12 partners. As educators, we have the professional wisdom to speak out for exemplary teaching and learning in Kansas.

Gather evidence on exemplary practice to continue to improve upon the work that we do, seeking to strengthen our programs and profession through meaningful research. Sharing this information at our state conference and journals such as The Advocate will be beneficial to all.

Embrace change. While it isn't always comfortable, it is inevitable. The needs of our workforce continue to change, therefore those of us preparing students for our future will see these changes. Change brings opportunity!

I hope while you enjoy this issue of The Advocate you find inspiration for your teaching, and are reminded to honor those who have preceded us while continuing to celebrate all that we do well.<smiles>CC(C)(C)CCC(C)(C)C</smiles>

Laurie J. Curtis, PhD

President, ATE-K

Kansas State University 
Editor's Statement

The Association of Teacher Educators-Kansas
Fall/Winter 2016-17

\section{The ATE-K ADVOCATE}

The ADVOCATE provides a forum for sharing research, editorial comments, especially teacher education in Kansas and across the country. This journal is online and can be accessed at: atekan.org, We are linked to the ATE national website.

ATE-K invites members as well as non-members to submit manuscripts on research and best practices related to: Teacher Education, Foundations, Technology, Supervision, Partnerships, Assessment, Professional Development, Curriculum, Innovations, Current Trends or "Theme Based" papers based on a tie-in with a National ATE meeting.

The journal is peer-reviewed. A fee of $\$ 20$ is required which also pays for a yearly (school year) membership. This money helps offset the costs for placing the journal online and to pay the web-content manager / layout editor. To check on membership and fee payment, contact:

Dr. Tim Fry, Exec. Dir. at Washburn University

(tim.fry@washburn.edu

Deadlines are found on our website, atekan.org We generally publish twice a year, Fall/Winter.....and.....Spring/Summer. PAST ISSUES CAN BE SEEN BY ACCESSING THE WEB-SITE AND CLICKING ON “JOURNAL.”

Articles should be send to me at: bquantic@yahoo.com. I live at 1213 N.Hamilton Circle, Derby, Kansas 67037

Sincerely,

H. Bruce Quantic, Ed.D.

Editor 


\title{
This Edition of The ATE-K ADVOCATE is Dedicated to:
}

\author{
Dr. Donald E. Hufford, Ph.D.
}

10/29/1929-9/27/2016

\section{ATE-K member and reviewer/author}

Don had a long and varied career in education. He was a retired Professor of Education at Newman University in Wichita where he taught for 24 years. He started there at age 61 when he was then the oldest professor at the University. He was a graduate of Kansas City Community College, Baker University, and the University of Kansas.

After attending Southern Methodist University in Dallas and Boston University, Don worked as a director at Morgan Memorial Youth and Children's Center in Boston's then-notorious South End. He encouraged youth to get off the streets and into an organized program, advice he continued to offer throughout his career.

Don was the founding Executive Director of Methodist Youthville at Dodge City, a residential treatment center for adolescent boys, for nearly 30 years. Don and his wife Evie had a tremendous impact on hundreds of boys, (serving as critical role models). After retiring there, Don and Evie began their post graduate work at K.U. His Ph.D.was in Philosophy of Education, his dissertation was entitled "Polarity Thinking in the Educational Philosophy of W.E.B. Du Bois."

Don was a prolific writer. He published in numerous journals and made many presentations at professional societies and associations throughout the country. $\mathrm{He}$ served as President of the Missouri Valley Philosophy of Education Society, President of the Society of Philosophy and History of Education. He was the keynote speaker for the 2009 Drake Lecture for the Educational Foundations Society.

The Society of Philosophy and History of Education dedicated its 2014 journal to him, stating (in their dedication, " $\mathrm{He}$ is a kind, thoughtful, and thinking man with experiences few educators have to bring to their teaching and scholarship. He has tread where few have had the courage and passion to pass and yet remains positive, affirming and relentlessly adamant that education improves individual lives and society at large."

\section{"Unconditional means no conditions - past, present, or future. Worth and Dignity are the birthrights of every child. They are not earned. They cannot be lost or neglected. THEY JUST ARE." - Don Hufford}




\section{THE ADVOCATE}

Fall - Winter 2017

When Study Abroad is Not Enough ; Improving Language Proficiency through Virtual Interaction

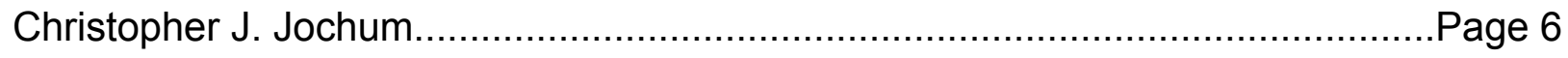

An Online Resource for Improving Instructional Practice

Daniel Stiffler and Mary Frazier...................................................... 13

Video-based Education Ethnography Project

Lori Goodson, F. Todd Goodson, and David S. Allen.................................Page 20

The Power of Classroom Libraries and Pre-Service Teachers

Sonja Ezell

Page 28

Benefits of a University Faculty-to-Faculty Mentoring Program

Anh Tran and Kay Gibson.

Page 34

Readstricted : Censorship in Public School Libraries

Carolyn L. Carlson. Page 55

Teacher Shortages in Kansas and in the Nation

Kenneth A. Weaver and Rudy Perez.

Page

61 


\section{Teaching Triangles: A Campus Wide Interdisciplinary Program for Faculty Professional Development}

Gwen Landever and Caroline Mackintosh....................................Page 72

$\underline{\text { Return-to-School Challenges for the Post-Concussion Student }}$

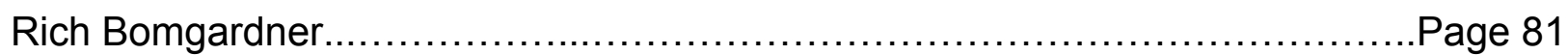

